\title{
Role of Glycosphingolipids in Formation and Function of Membrane Microdomains
}

\author{
細胞膜ミクロドメインの形成と機能におけるスフィンゴ糖脂質の役割
}

\begin{abstract}
Masserini, Massimo; Ravasi, Daniela; and Sonnino, Sandro*
Department of Experimental, Environmental Medicine and Biotechnology, University of Milano-Bicocca, Via Cadore 48, 20052 Monza, Italy; *Study Center for the Functional Biochemistry of Brain Lipids, Department of Medical Chemistry and Biochemistry - LITA, University of Milano, Via Fratelli Cervi 93, 20090 Segrate, Italy

FAX: 39-02-6448-8250, E-mail:massimo.masserini@unimib.it
\end{abstract}

Key Words : glycosphingolipids, domains, lipid rafts, caveolae

\begin{abstract}
Recent years have been characterized by a huge interest in the structure and function of mammalian cell membrane lipid domains. The interest in this subject grew further, when their participation in important membrane-associated events such as signal transmission, cell adhesion and lipid/protein sorting was postulated. A common feature of cell membrane domains is their peculiar lipid composition, being enriched in glycosphingolipids, sphingomyelin and cholesterol. A series of theoretical considerations and several experimental data suggest that glycosphingolipids play an important role in the formation and function of membrane domains. Within this review, the involvement of glycosphingolipids in the biogenesis, structure and function of domains is discussed in light of their strong amphiphilic nature and of their peculiar chemical features. These features differentiate glycosphingolipids from other lipids in the membrane, allowing either self-interaction or interaction with other membrane components and external ligands. Due to these interactions, glycosphingolipids undergo lateral phase separation, segregation, and therefore form core domains within the membrane; glycosphingolipid domains constitute the nucleation point that allows co-segregation of other lipids and proteins in a complex domain; finally, glycosphingolipids confer dynamic properties on domains, that are essential to the modulation of cell functions.
\end{abstract}

\section{要 約}

近年、哺乳類の細胞膜ドメインの構造や機能への関心 が高まり、特に膜を介したシグナル伝達、細胞接着、脂質 ノタンパク質複合体の選別機構への関与が興味の対象と なっている。細胞膜ドメインに共通した特徵は、スフィン ゴ糖脂質、スフィンゴミエリン、コレステロールなどの脂 質が主要な成分を構成している特異な脂質組成にある。一 連の理論的考察といくつかの実験データからスフィンゴ糖 脂質がドメインの形成や機能において重要な役割を果たし ていることが示唆されている。この総説ではドメインの生 成、構造、機能におけるスフィンゴ糖脂質の関与につい て、この分子の強い両親媒性や特異な化学的性質に着目し て論議する。これらの性質によりスフィンゴ糖脂質はその 他の膜脂質と区別され、自己会合したり他の膜構成成分や 外部のリガンドなどと相互作用することが示唆されてい る。また、これらの相互作用によりスフィンゴ糖脂質は相 分離を起こし、膜上でドメインの核を形成する;すなわち スフィンゴ糖脂質ドメインは他の脂質やタンパク質を含む 複雑なドメイン形成の中心的役割を果たしている。以上の ことから、スフィンゴ糖脂質はドメインに動的性質を付与

し、細胞機能の調節に不可欠であると考えられる。

\section{A. 序 論}

細胞膜は、脂質とタンパク質の超分子凝集体からなる特

It is common knowledge that cell membranes contain specialized domains, that is supramolecular aggregates of lipids and proteins, that have been shown to display dynamic properties and accomplish important functional tasks (1-5). In fact, the participation of domains has been postulated in several cell membranelocated events, ranging from signal transduction, lipid/protein sorting and cell adhesion to cell growth and apoptosis $(2,6,7)$. In the case of a particular type of domain, caveolae, the involvement in cellular transport processes has also been pointed out $(4,8-10)$.

In spite of the plethora of nicknames that domains have received (lipid rafts, DIGs, DRF, GED, GEM, detergent-resistant
別なドメインを含むことから動的性質を示し、細胞機能に重 要な役割を果たしていると考えられている(1-5)。実際に、シ グナル伝達、脂質/タンパク質の選別や細胞接着に始まり細胞 増殖やアポトーシスなどの細胞膜で起こる様々な現象へのド メインの関与が提唱されている $(2 、 6 、 7)$ 。カベオラを含む特 殊なドメインの場合には、細胞内の輸送機構との関与も示唆 されている(4、8-10)。ドメインにはスフィンゴ糖脂質やス フィンゴミエリン、またはコレステロールが豊富に存在して おり、 lipid rafts、DIGs、DRF、GED、GEM、 detergent-re- 
domains, caveolae, caveolae-like domains, flat caveolae, glycosignaling domains), they show a characteristic enrichment in glycosphingolipids, sphingomyelin and cholesterol (11-19). It is important to remember that domains isolated from a variety of cells that express GM1 ganglioside are typically enriched in this glycosphingolipid, often used as their lipid marker $(3,8$, $13,17-23$ )

A series of theoretical considerations suggests that, among the molecules present, glycosphingolipids could play an important role in domain biogenesis and function. In fact, glycosphingolipids undergo spontaneous segregation: this feature has been proven both in cellular and artificial membranes $(24,1,25)$; moreover, glycosphingolipid segregation is susceptible to modulation: for instance, by specific stimuli able to activate protein kinase $\mathrm{C}$ (PKC) $(26,27)$, and by external ligands $(20,28,29)$; finally, glycosphingolipids are able to affect, upon interaction, the structure and function of several molecules (30).

\section{B. Glycosphingolipid Structure}

Glycosphingolipids (31) are glycoconjugates composed of a saccharide hydrophilic portion linked to ceramide, the hydrophobic moiety.

The ceramide portion is formed by a long chain base (LCB) linked to a fatty acid. The prevailing LCB species in cerebrosides and sulfatides (and in sphingomyelin) is the unsaturated form carrying $18 \mathrm{C}$ atoms, $\mathrm{C}_{18}$-sphingosine, followed by the saturated form, $\mathrm{C}_{18}$-sphinganine. In addition to these, gangliosides also carry quite large amounts of the species having 20 carbons. The fatty acid moiety present in ceramide is extremely heterogeneous, comprising molecules of different length, unsaturation and hydroxylation.

\section{Role of Glycosphingolipids in the Assembly and Maintainance of Membrane Domains}

Glycosphingolipids play a pivotal role in the biogenesis and maintenance of domain architecture thanks to their physicochemical properties. Glycosphingolipids are characterized by a strong amphiphilic nature and by peculiar chemical features. Both these characteristics render them different from other partner lipids in the membrane. Through their ceramide portion, embedded into the lipid bilayer of the membrane, they are able to interact with other lipids or with integral membrane proteins. Their oligosaccharide hydrophilic moiety, protruding from the membrane surface, allows their interaction either with other membrane components or with external ligands. Finally, both the hydrophilic and the hydrophobic moiety of their molecule allow self- interaction.

The above mentioned features suggest that glycosphingolipids bring a specific contribution to the biogenesis and function of domains in at least three ways: 1 . they form sistant domains、caveolae、 caveolae-like domains、 flat caveolae、 glycosignaling domains と多くの別称がある(11-19)。GM1ガング リオシドを発現している細胞から分離されたドメインにはGM1 が集積しており、ドメインの脂質マーカーとしてよく利用されて いる(3、8、13、17-23)。一連の理論的考察から、スフィンゴ糖 脂質はドメインの生合成や機能において重要な役割を果たしてい ると考えられる。実際、スフィンゴ糖脂質が自然に相分離を起こ していることは、細胞と人工膜の両方で実証されている $(1 、 24 、$ 25)。また、プロテインキナーゼC(PKC)を活性化するような刺激 や(26、27)、細胞外リガンドなどの因子 $(20,28,29)$ によスフィ ンゴ糖脂質の相分離が調節される。以上のことから、スフィンゴ 糖脂質はいくつかの分子の構造や機能に影響を及ぼす、もしくは 相互作用を起こす事ができると考えられる(30)。

\section{B. スフィンゴ糖脂質の構造}

スフィンゴ糖脂質は親水性の糖鎖部分と疎水性のセラミ ド部分が結合して構成されている(31)。

セラミド部分は長鎖塩基と脂肪酸で構成されている。セ レブロシドやスルファチド(スフィンゴミエリンも含む)に多く 含まれているのは長鎖塩基の炭素数が18個で不飽和型のC-18 スフィンゴシンもしくは飽和型のC-18スフィンガニンであ る。一方、ガングリオシドは長鎖塩基の炭素数が 20 個のもの が多い。セラミドの脂肪酸部分は非常に不均一で、異なる長 さの分子を含み、不飽和であったり水酸基を含んだりしてい るものもある。

\section{C. ドメインの構築や維持におけるスフィンゴ糖脂質の役割}

スフィンゴ糖脂質は、それらの物理化学的性質によりドメ インの生成や構造の維持において中心的な役割を果たしてい る。スフィンゴ糖脂質は強い両親媒性と特有の化学的性質に よって特徴づけられる。この二つの性質を合わせ持つことが他 の膜脂質と異なるところである。セラミド部分は脂質二重膜へ 埋込まれており、他の脂質や膜タンパク質と相互作用すること ができる。親水性のオリゴ糖部分は膜表面に突出しており、他 の膜構成成分や細胞外リガンドとの相互作用を可能にしてい る。また、スフィンゴ糖脂質は親水性部分と疎水性部分のそれ ぞれが自己会合することもできる。

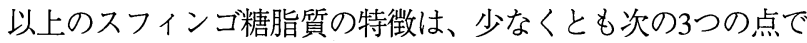
ドメインの生成および機能に貢献していることを示唆している。

1）スフィンゴ糖脂質は自発的な相分離によりドメインの核 
a core domain thanks to their spontaneous segregation properties; 2. glycosphingolipid domains constitute a nucleation point for the co-segregation of other lipids and proteins in a complex domain; 3. glycosphingolipids confer dynamic properties on domains.

\section{C-1. Glycosphingolipids Constitute a Core, Spontaneously Segregating Domain}

Clustering of gangliosides within membranes composed of other lipids, e.g. glycerophospholipids, is a complex phenomenon. In order to render its comprehension easier, the contribution of different parameters will be separately taken into account, and the influence of chemical and geometrical features will be discussed.

\section{C-1-1. Chemical Features}

A unique feature of sphingolipids is the characteristic presence of hydroxy- and amido- groups in the ceramide moiety, enabling them to act as hydrogen bond donors and acceptors at the same time $(25,32)$. Therefore, glycosphingolipids form a network of intermolecular lateral hydrogen bonds at the level of the ceramide portions and undergo spontaneous segregation in domains or co-segregation with other sphingolipids (25). This feature is not shared by glycero-phospholipids, that can act only as hydrogen bond acceptors and are not known to undergo spontaneous formation of domains.

It has often been suggested that clusterization could be facilitated and promoted by the formation of side-by-side oligosaccharide interactions. This has been explored using micellar aggregates of gangliosides: at the micelle surface of the monomers' head groups are packed so closely that intermolecular carbohydrate-carbohydrate interactions could take place. However, no experimental evidence of intermolecular carbohydratecarbohydrate interactions has been observed (33). This striking result is probably the consequence of the large amount of water present in the hydrophilic layer of the micelle, being an obvious component of the sugar shell. Water is attracted by the hydrophilic sugar moieties and avoids repulsion between negative charged oligosaccharides, when the latter are present. It has been determined that each saccharide chain is surrounded by 40-70 water molecules (34). The presence of water would prevent any direct inter-monomer carbohydrate-carbohydrate interactions at the level of cell membrane, where local glycosphingolipid concentration is always likely to be lower than in micelles.

\section{C-1-2. Physico-chemical Features}

The segregation of glycosphingolipids with respect to other partner lipids within the membrane is a spontaneous process, driven by general thermodynamic laws, that is minimization of the interfacial free energy. Both the primary (chemical composition) and the secondary (conformation of the oligosaccharide chain) structure of glycosphingolipids affect their segregation.
を形成する。

2）ドメイン複合体の中で、他の脂質やタンパク質との協調 した相分離を可能にするスフィンゴ糖脂質ドメインともいうべ き核を形成する。

3）スフィンゴ糖脂質はドメインに動的な性質を付与する。 C-1. スフィンゴ糖脂質は自発的な相分離によりドメインの核を 形成している。

グリセロリン脂質などのような別の種類の脂質を含む膜で のガングリオシドの集合は複雑な現象である。そこでわかりや すいように異なるパラメーターの寄与(化学的性質によるもの と、形によるもの)は別々に考察する。

\section{C-1-1.化学的性質}

スフィンゴ脂質のユニークな性質は、セラミド部分にある

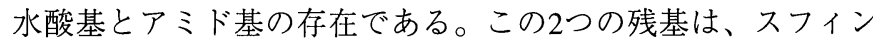
ゴ脂質に水素結合供与基と受容基の両方の機能を与えている (25、32)。それゆえに、スフィンゴ糖脂質はセラミド分子同士 で水素結合し分子間ネットワークを形成し、他のスフィンゴ脂 質と共にドメイン中で自発的相分離を起こしている(25)。この 性質は水素結合受容基しかもたないグリセロリン脂質にはな く、グリセロリン脂質によるドメイン形成もこれまでに知られ ていない。隣接する糖鎖同士の相互作用によるクラスタリング の促進の可能性が以前から示唆されていた。ミセル表面では糖 鎖-糖鎖相互作用が起こり得るくらい糖残基モノマーは近接し ていると考えられることから、ガングリオシドのミセル凝集に も糖鎖相互作用の関与が検討された。しかしながら、分子間で の糖鎖-糖鎖結合の実験的証拠はまだ得られていない(33)。この 結果の理由としては、ミセル表面の糖鎖が親水性であり、水分 を多く引き付けていることが要因であることが考えられる。水 は親水性糖鎖によって引き付けられ、負の電荷をもつ糖鎖間で の反発を防いでおり、それぞれの糖鎖はおよそ40から70の水分 子によって囲まれている(34)。㧍そらくこの糖鎖に引き寄せら れた水分子が、スフィンゴ糖脂質の濃度がミセルょりも低い細 胞膜でも直接的な糖鎖-糖鎖間の相互作用を妨げているのかも 知れない。

\section{C-1-2.物理化学的性質}

膜上におけるスフィンゴ糖脂質は、他の脂質との間で熱力 学的に安定になろうとする性質によって相分離を起こす。この 分離には、スフィンゴ糖脂質の一次構造(化学組成)と2次構造(オ リゴ糖鎖の立体構造)が影響している。 


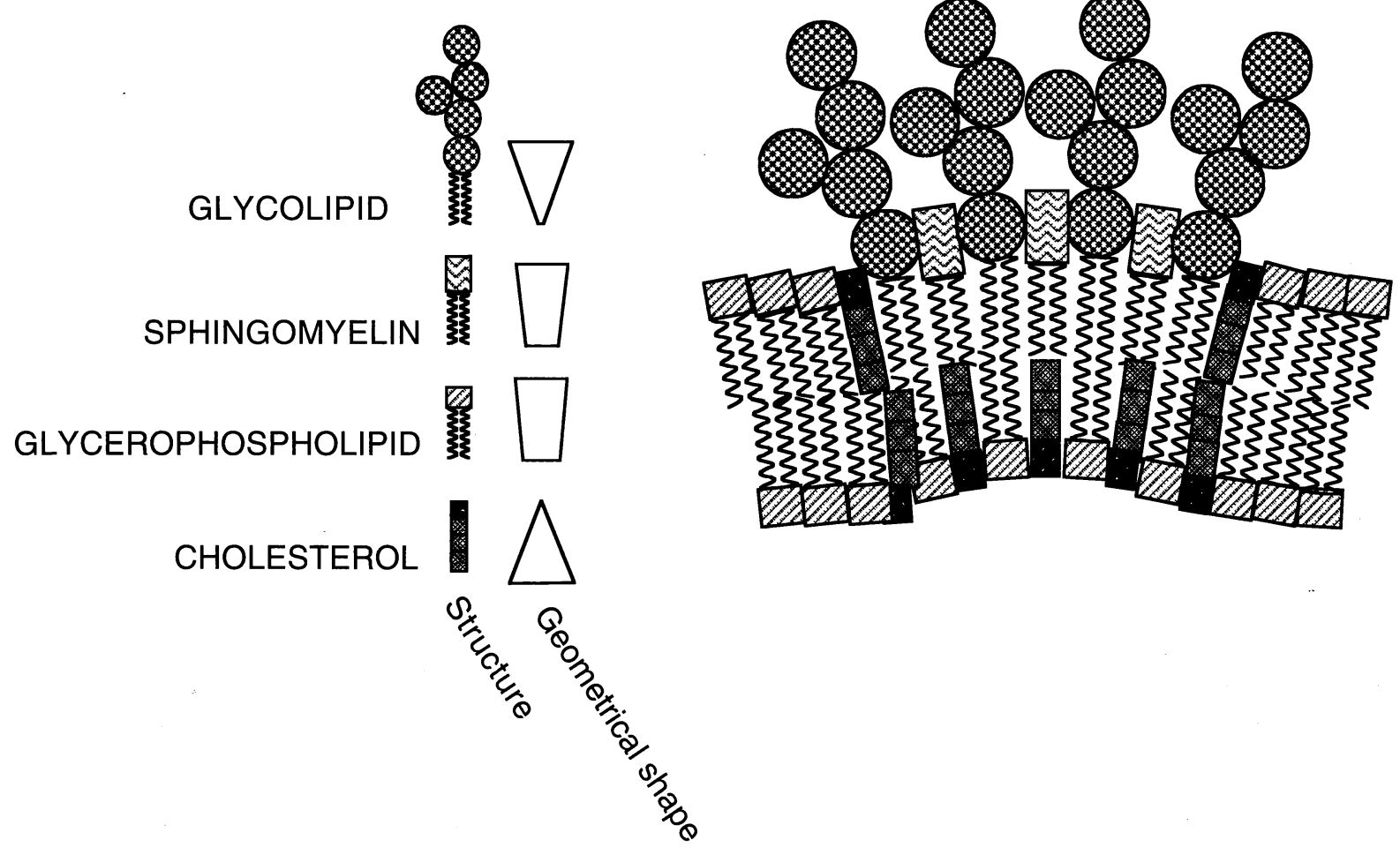

Fig. 1. Representation of a membrane glycolipid domain. The outside orientation of the membrane curvature is inferred with the geometrical parameters experimentally determined by laser light scattering measurements on membrane models; the higher content of cholesterol in the inner layer of the membrane is inferred from literature data (see text for details).

As a first general consideration, in a glycosphingolipidembedding mixed system their segregation is made possible by the existence of different lipid monomers carrying headgroups with very different geometrical characteristics.

In comparison with other membrane lipids, e.g. glycerophospholipids, the glycosphingolipid head group is very hydrophilic and protruding from the membrane surface. Thus, they require a membrane surface area large enough to host the oligosaccharide chain and its hydration water, in the hydrophilic layer of the membrane. The larger the interfacial area, the stronger the membrane curvature, the more pronounced the segregation. The hypothetical structure of a membrane domain is reported in Fig. 1.

The surface area occupied by glycosphingolipids at the water-lipid interface of the membrane has been determined for a large number of ganglioside species, carrying the same hydrophobic portion, using membrane model systems. The values are reported in Table I. As would be predicted, the surface area occupied by a monomer inside the membrane increases on increasing the hydrophilic character $(\mathrm{GM} 3<\mathrm{GM} 2<\mathrm{GM} 1$ $<$ GD1a $<$ GT1b) of the ganglioside, that is on increasing the number of saccharide residues. In fact, as the number of sugar units
まず第一に、スフィンゴ糖脂質を含む膜で相分離がおこる のはスフィンゴ糖脂質の糖鎖部分の構造にきわめて特徵がある からである。グリセロリン脂質などの他の膜脂質と比較してみ ると、スフィンゴ糖脂質の頭部 (糖鎖)部分は非常に親水性であ り、膜上に突出している。それゆえに、疎水性の膜表面には才 リゴ糖やオリゴ糖に水和した水を納めるのに充分な領域が必要 となる。この領域が大きくなればなるほど、膜の弯曲が起こ り、より明瞭な相分離が起こると考えられる。図1はこの仮説を 示すモデル図である。

膜モデル系を用いた実験により疎水性部分は同じ構造をも つ多種類のガングリオシドについて糖鎖部分の占める面積が求 められている。その值を表 1 に示した。予想されるように、糖の 数が増えて親水性が増加するにつれて占有面積は広くなる $(\mathrm{GM} 3<\mathrm{GM} 2<\mathrm{GM} 1<\mathrm{GD} 1 \mathrm{a}<\mathrm{GT} 1 \mathrm{~b})$ 。実際、糖残基が増すごとに親 水性の反発力が与えられ、糖鎖部分を収容するには広い面積が 必要となりより弯曲した大きな分域を必要とする。しかしなが 
increases, a stronger hydrophilic repulsive contribution is given, thus the molecule requires a larger interfacial area and the segregated area becomes more curved. However, the hydrophilicity of the extended and branched structure of ganglioside headgroups cannot always be easily evaluated, and other constraints play an additional role. For instance, the behaviour of GD1a, GD1b and GD1b-L is different, even if they are carrying the same number of saccharide residues. The different contributions that affect this behaviour can be evaluated as follows.

As a consequence of a net of interresidual interactions, the trisaccharide sequence GalNAc-Gal-Neu5Ac, shared by a number of gangliosides, is considered to be a compact superunit $(35,36)$. Any interaction between the side chain of sialic acid, which is in a rigid conformation, and $\mathrm{N}$-acetyl-galactosamine brings about a strong association between Neu5Ac and GalNAc units. This association is probably stabilized by a hydrogen bond between the GalNAc amide proton and the Neu5Ac carboxyl group. The addition of a sialic acid residue to the GalNAc-GalNeu5Ac trisaccharide, as in GD1b, introduces conformational changes (37). The interresidual contacts between GalNAc and the inner Neu5Ac are lost, while interactions between GalNAc and the external Neu5Ac are present. According to these constraints, the tetrasaccharide chain GalNAc-Gal-Neu5Ac-Neu5Ac in GD1b is arranged in a circle with a hole about $3 \AA$ wide in the center. The internal surface of this hole is highly hydrophobic since seven apolar groups point towards the center. Such a conformation confers a bulkier character to the ganglioside portion closer to the hydrophobic-hydrophilic interface. Therefore, the disialyl chain close to the hydrophilic-hydrophobic interface of GD1b requires a wide solid angle to be hosted within the membrane. It is possible to predict that GD1b requires more space if compared with GD1a, where the second sialyl moiety is linked to the external galactose unit .

Instead, the surface area required by GD1b-L is lower than GD1b and close to that of GD1a; this means that in GD1b$\mathrm{L}$ it is no longer necessary to increase the solid angle, as in GD1b, to locate the second sialic acid. In fact, the presence of the lactone ring in GD1b-L induces changes in the three dimensional structure (37). The interresidual interactions between GalNAc and the external Neu5Ac take no longer place, while the compact conformation of the GalNAc-Gal-Neu5Ac, observed in GM1 and GD1a, is still present. This forces a better lining up of the disialosyl chain with the neutral oligosaccharide chain, reducing the angle between the neutral chain and the inner sialic acid axis. The resulting effect is a reduction in the "optimal surface area" occupied by the lactonized GD1b at the hydrophobic-hydrophilic interface.

A significant contribution is also exerted by the lipid portion, ceramide. Table I reports data obtained on GM1 ganglioside molecular species containing different ceramide moieties. The results are compared with natural GM1, i.e. GM1
ら、糖鎖部分の伸長および分岐したガングリオシドの親水性 は、糖鎖組成が同じでも容易には評価出来ない。実例として、 GD1a、GD1b、およびGD1b-L(ラクトン体)の挙動は異なってい る。この挙動の相違は次のように説明することができる。

糖残基間相互作用の観点からは、多くのガングリオシドが 有するGalNAc-Gal-Neu5Acの三糖構造は最小の単位構造とみな される $(35 、 36)$ 。強固な配座をとっているシアル酸側鎖とN-ア セチルガラクトサミン間の相互作用は両糖残基の会合を強めて いる。この相互作用はおそらくN-アセチルガラクトサミンのア ミド基のプロトンとN-アセチルノイラミン酸のカルボキシル基 との水素結合により安定化している。GD1bのようにGalNAcGal-Neu5Ac構造にシアル酸が付加すると、立体構造が変化する (37)。N-アセチルガラクトサミンが外側のN-アセチルノイラミ ン酸と相互作用している際には、糖鎖内部のN-アセチルノイラ ミン酸との会合は起こらない。これらの制約により、GD1bの GalNAc-Gal-Neu5Ac-Neu5Acの四糖構造は、中心に3Åの穴を形 成する。この穴の内部表面は、7つの無極性基から成る高い疎水 性を示す。この構造は、親水性-疎水性境界に近接したガングリ オシドに対して、かさ高い性質を与えている。それゆえに、 GD1bの場合、親水性-疎水性境界近傍のジシアリル基は膜内に おさまるための広い強固な配向性を必要とする。よって外側の ガラクトースにもう一つのシアル酸が結合しているGD1a と比較 すると、GD1bはより広い領域を必要とすることが予想される。

一方、ラクトン体であるGD1b-LはGD1bより少ないスペー スでよく、GD1aに近い。それは、GD1b-LはGD1bのように2個 目のシアル酸を配置するための強固な配向を持つ必要がないこ とを意味する。事実、三次元構造に変化をもたらすラクトン環 の形成がGD1b-Lで認められている(37)。ラクトン化している ために外側のN-アセチルノイラミン酸とN-アセチルガラクト サミンとの相互作用は起こらず、GM1 PGD1aにみられるよう なGalNAc-Gal-Neu5Acの密な構造が保持されている。従って、 内側のシアル酸と中性糖鎖の結合角は減少し、中性オリゴ糖鎖 でジシアリル基はよりょく裏打されるようになる。そのために ラクトン化したGD1bの糖鎖の占める面積はGD1bよりも小さく なる。

脂質部分のセラミドも糖鎖の占める面積に対して物理化学 
Table I. The surface area $a\left(\AA^{2}\right)$ for different gangliosides calculated from the packing parameter $P=V / a l$ of the monomer in the aggregate, where $l$ is the maximum lipid chain length and $V$ the hydrophobic volume per monomer. The packing parameter is related to the shape of aggregate [(spherical micelles $(P<1 / 3)$, non-spherical micelles $(1 / 3<P<1 / 2)$, bilayers $(1 / 2<P)]$. ${ }^{a}$ When not specified, the ganglioside sialic acid is the $N$-acetylneuraminic acid (Neu5Ac), and the ceramide moiety is constituted by a mixture of $\mathrm{C} 18$ and $\mathrm{C} 20$ unsaturated LCB (about 1:1) and stearic acid ( $>90 \%$ of the total fatty acid content).

The sphingoid base(LCB) contained a mixture of 18 and $20 \mathrm{C}$ atoms.

\begin{tabular}{lccc}
\hline & $a$ & $P$ & reference \\
\hline GM3 & & & \\
GM2 & $\sim 80$ & $>0.5$ & $(55)$ \\
GM1(LCB:1, C18:0) & 92.0 & 0.440 & $(56)$ \\
GM1(Neu5Gc) & 95.4 & 0.428 & $(57)$ \\
GD1a & 93.8 & 0.437 & $(58)$ \\
GalNAc-GD1a & 98.1 & 0.416 & $(57)$ \\
GD1b & 97.0 & 0.421 & $(36)$ \\
GD1b-L & 100.8 & 0.405 & $(59)$ \\
GT1b & 97.6 & 0.418 & $(59)$ \\
GM1(LCB:1,C2) & 100.8 & 0.405 & $(56)$ \\
GM1(LCB:1,C180H:0) & 64.8 & 0.370 & $(60)$ \\
GM1(LCB:0,C18:0) & 93.0 & 0.438 & $(61)$ \\
& 96.3 & 0.433 & $(57)$ \\
\hline
\end{tabular}

(LCB:1,C18:0).

The saturation of LCB of GM1(LCB:0,C18:0) leads to an increase in the surface area occupied by the monomer; this change could also come from the maximum chain length $l_{c}$. In GM1 LCB:1,C18:0 the double bond close to the headgroup favours the parallel orientation of the axes of the two hydrocarbon chains. The lack of the double bond allows the hydrocarbon chain of the LCB to straighten up, its axis forming an angle with the fatty acid axis, and causing an overall reduction in the maximum chain length.

The extent of the hydrophobic contribution to the aggregation properties is quite evident if one looks to the semisynthetic GM1(LCB:1,C2) ganglioside. The almost complete removal of the second lipid chain, corresponding to the substitution of an extended fatty acid with an acetyl group, reduces the hydrophobic volume of the molecule by $42 \%$. Consequently, both the packing parameter and the surface area of GM1(LCB:1,C2) become smaller.

The data on the GM1 molecular species containing 2hydroxy-stearic acid as the fatty acid moiety, GM1(LCB:1,C18OH:0) are very interesting. The presence of the fatty acid hydroxyl group increases the "hydrophilicity" of the molecule with respect to natural GM1 suggesting that GM1(LCB:1,C18OH:0) should require a larger surface area at the membrane surface: nevertheless this ganglioside has been observed to pack tighter than GM1. Indications coming from $\mathrm{X}$-ray measurements, performed on GlcCer containing 2-hy-
的に有意な影響を及ぼしている。表1では異なるセラミド部分を 持つGM1についてのデータを示し、天然GM1 (LCB：1、C18： 0)と比較している。飽和型の GM1(LCB：0、C18：0)では膜上で モノマーの占める面積が増加している。この変化は、最大鎖長 lcに依存している。GM1(LCB：1、C18：0)の二重結合は二本の 炭素鎖を平行にしている。二重結合がなくなると長鎖塩基が つっぱって脂肪酸鎖と角度をなすので垂直方向の長さ(最大鎖長) は減少する。

疎水性基も糖鎖の占有面積に対して影響をもつこととはGM1 合成アナログ(LCB:1, C2)の結果をみるとよくわかる。殁どのア シル側鎖が除かれアセチル基に置換されたこの分子では、1分子 あたりの占有体積が $42 \%$ も減少していた。その結果として、C2GM1のパッキングパラメータ(表Iの脚注参照)と占有面積は、共 に隇少する。

脂肪酸部分に 2 -ヒドロキシステアリン酸をもつGM 1 (LCB：1、C18OH：0)では、非常に興味ある現象が観察され た。天然のGM1より親水性の高くなったこの分子は、膜表面上 でより大きな領域を必要とすると予想されるにもかかわらず、 
Trends in Glycoscience and Glycotechnology Vol.13 No.71 (May 2001) pp.239-250

droxy fatty acid (38) or normal fatty acid (39) in a single crystal phase, suggest that only minor differences are present in the torsional angles of the polar ceramide side of the two compounds, while the 2-OH group has been observed to be involved in intermolecular hydrogen bonding. The presence of the $\mathrm{OH}$ group on the fatty acid, which is disposed in an anti-periplanar conformation with respect to $\mathrm{C}=\mathrm{O}$, in order to allow its implication in intermolecular hydrogen bonding, may cause a LCB compensating rearrangement which could give rise to the observed differences in the coupling constants and favour, on the other side, a more cylindrical packing of the monomer in the aggregate structure.

As proof of the influence of the above reported parameters on the segregative properties of glycosphingolipids, and of the correctness of the above considerations, are the results obtained on phospholipid vesicles embedded with i) ganglioside molecules carrying the same ceramide moiety and different oligosaccharide chains, or ii) ganglioside molecules carrying the same oligosaccharide portion and different ceramide moieties. In fact, the results obtained using such membrane model systems, studied by differential scanning calorimetry which is able to detect lipid lateral phase separation, showed that: i) the tendency of glycosphingolipids to segregate into domains increases on increasing the number of saccharide units; in particular, for a given number of saccharide residues, the segregation is not dependent on the number of sialic acid moieties in the hydrophilic chain $(1,40,41)$; ii) For a given oligosaccharide chain, the tendency to segregate into domains depends on the differences in the lipid moiety between embedded glycosphingolipid and hosting phospholipid membranes. The glycosphingolipid species displaying the stronger differences (length, saturation) undergo lateral phase separation.

The role of the size of the oligosaccharide chain of gangliosides in promoting a segregation phenomenon has also been observed in an ellipsoidal micellar system of GM2 and GT1b, carrying 4 and 7 sugar units, respectively. The spontaneous spatial segregation of GM2 with respect to GT1b is explainable by the fact that the large headgroup of GT1b provides the lipidic core of the aggregate with a better shielding from water in the highly curved regions than the smaller headgroup of GM2 can do.

As a final consideration, it should be said that the presence of cholesterol, reported to be enriched in the inner leaflet of the membrane $(42,43)$ can also contribute to the curvature of the membrane lipid domain (Fig. 1).

In conclusion, both the chemical and physical characteristics of the glycosphingolipid molecule could supply a driving force inducing glycolipid segregation. In this view, glycosphingolipids constitute a self assembling supramolecular aggregate, which constitutes a core membrane domain around which other molecules can gather, forming a more complex do-
実は密にパッキングされているのである。2位に水酸基をもつ 脂肪酸(38) と水酸基をもたない脂肪酸(39)を含むグルコシルセ ラミドのX線結晶解析の結果を比較すると、セラミドの極性部 分の角度には差はないが、2位の水酸基は分子間相互作用に寄 与していることがわかった。 $\mathrm{C}=\mathrm{O}$ 結合とは同一平面上にない 水酸基が分子間相互作用にかかわるならば、LCB部分の向きは 変化しているはずであり(カップリング定数の変化の原因と考 えられる)、そのため脂肪酸の2位に水酸基があるとLCB部分は 脂肪酸に寄り添い円筒状に密なパッキング状態をとると考えら れる。

以上のスフィンゴ糖脂質の相分離に関してのパラメータゃ 考察の確実性は、i) 同じセラミド部分と異なる糖鎖部分を持つ ガングリオシド分子または、ii) 異なるセラミド部分と同じ糖鎖 部分を持つガングリオシド分子を胞埋したリン脂質小胞を用い た実験より得られる。実際、これらのモデル膜実験系を用いた 示差熱測定法により脂質の相分離について分析した結果は、i） ガングリオシドのドメイン内での相分離傾向は糖鎖の数が増す につれて増加していく傾向にある。特に、糖の数が重要であ り、シアル酸の数は関係ない $(1 、 40 、 41)$ ；ii) オリゴ糖部分が 同じである場合の相分離の傾向は、リン脂質とスフィンゴ糖脂 質の脂質部分の違いに依存している。スフィンゴ糖脂質の脂質 部分の長さや飽和度は相分離に大きく影響している。相分離現 象におけるガングリオシドの糖鎖部分の大きさの役割は、それ ぞれ4つと7つの糖残基を有するGM2、GT1bの棈円体ミセルの形 成においても見られる。GM2よりも糖鎖部分の大きいGT1bは膜 に高い弯曲領域を与え、水を遮蔽した脂質コアを形成し、より 高率に自発的な相分離を引き起こす。さらに、図1で示したよう に膜脂質ドメインが細胞の外側につきでて彎曲していること は、コレステロールが内膜側に豊富に存在しているという報告 (42、43)からも支持される。結論として、スフィンゴ糖脂質分 子の化学的および物理的性質が相分離にドライビングフォース を与えている。この点から、スフィンゴ糖脂質は自己会合に よって超分子複合体を形成し、他の分子が集合可能な核を形成 し、より複雑なドメインを形成する中心的役割を果たしている 
Trends in Glycoscience and Glycotechnology

Vol.13 No.71 (May 2001) pp.239-250

main.

\section{C-2. Glycosphingolipid domains are a nucleation point for co-segregation of other lipids and proteins.}

Other molecules could join in a second time the initial core domain formed by the clustered glycosphingolipid molecules, expanding domain size and complexity. This could be the reason why some proteins are enriched within domains. However, it should be noticed that the variety of proteins that has been detected within glycosphingolipid-enriched domains is surprisingly wide, contrary to the relatively simple lipid composition of domains. In fact, proteins of the caveolin family (44) are enriched within these membrane compartments, and utilized as their markers; cell signaling components, e.g. GPI-anchored proteins, non-receptor and receptor tyrosine kinases, mono- and heterotrimeric GTP-binding proteins are among the proteins that contribute to the complex glycosphingolipid-enriched domain composition $(17,22,44)$. Domains have also been found to contain adapter molecules, known to function as intermediates in tyrosine kinase signal transmission (17). Finally, membrane domains have been found to be enriched in molecules mediating cell growth and cell adhesion (22).

Given the great variety of proteins detected in glycosphingolipid-enriched domains, it seems improbable, with a few exceptions, that all of them can be recruited by specific interaction. Among the exceptions are those described for tyrosine kinase receptors and caveolin shown to interact with GM1 ganglioside $(21,45)$. Therefore, it is likely that the core glycosphingolipid-enriched domain gathers other molecules by weak, non-specific, interactions. Glycoproteins are among the possible candidates, since studies carried out on model membranes (41) have shown that glycoproteins and glycosphingolipid domains can affect and modulate each other $(40,41)$. A similar mechanism, could be the case for GPI-anchored proteins, either interacting with each other or with glycosphingolipids through their various saccharide, and inositol, residues, and undergoing segregation into glycosphingolipid-enriched domains.

\section{C-3. Dynamic Properties of Domains}

Given the weak, transient nature of the interactions occurring among lipids and other molecules inside glycosphingolipid-enriched domains, it can be is predicted that such domains are characterized by substantial dynamic properties. So far, this hypothesis has been confirmed by several investigations.

For instance, previous experiments have shown that glycosphingolipid domains are subject to spontaneous time evolution (46). It is likely that lateral diffusion of molecules is responsible for the local changes of concentration, by continuously varying the composition of a given membrane zone. On the other hand, more specific interactions, can counteract this trend, conferring stability on domains. In this sense are the
と言うことができる。

C-2-2.スフィンゴ糖脂質ドメインは他の脂質やタンパク質との 協調した相分離における核を形成している

スフィンゴ糖脂質がまず自己会合により最初のドメインの 核を形成し、その次にスフィンゴ糖脂質以外の分子が集合し、 ドメインのサイズと複雑さが増す。これがドメイン内に幾つか のタンパク質が豊富に含まれる理由であろう。実際には、ドメ インの脂質組成が単純であるのに反して、さまざまなタンパク 質が驚くほど広範囲に渡ってドメイン内で確認されている。カ ベオリンファミリーのタンパク質はドメイン中に豊富に存在し (44)、ドメインのマーカーとして利用されている。細胞シグナル 伝達物質であるGPIアンカータンパク質、受容体、もしくは非受 容体型チロシンキナーゼタンパク質、単量体もしくは三量体 GTP結合タンパク質などは糖脂質ドメインの成分となっている (17、22、44)。ドメインは、チロシンキナーゼのシグナル伝達を 仲介する機能をもつアダプター分子も含んでいる(17)。従っ て、膜ドメインは細胞増殖および細胞接着を調節する分子を豊 富に含んでいる(22)。

スフィンゴ糖脂質ドメインに存在するタンパク質の多く は、幾つかの例外を除けば、それぞれに特異的な相互作用に基 づいて膜へリクルートされるわけではない。例外のなかに は、GM1と相互作用するチロシンキナーゼ受容体やカベオリン などがある(21、45)。コアとなるスフィンゴ糖脂質ドメインは他 の分子を弱く、非特異的に集積すると考えられる。いままでの 研究により、糖タンパク質と糖脂質がモデル膜内でお互いに影 響し合っていることから(41)、糖タンパク質が非特異的に集積す る可能性がある(40、41)。似たような機構としては、GPIアン カータンパク質同士、またはスフィンゴ糖脂質とGPIの糖鎖部分 やイノシトールとの相互作用を介しての相分離が挙げられる。

\section{C-3.ドメインの動的性質}

糖脂質ドメインにおける脂質と他の分子との弱い一過性の 相互作用は、このドメインがかなり動的な性質を持つことを予 想させる。この仮説は幾つかの研究によってこれまでに確認さ れている。たとえば糖脂質ドメインには時間とともに自発的に 変化をすることが観察されている(46)。

これは膜の構成成分が連続的に変化することによって、膜 内分子の濃度変化が引き起こす分子の拡散が生じるからであろ う。しかし一方では、より特異的な相互作用がこれらの傾向を 相殺し、ドメインの安定性を保持している。これはグリコホリ ンに関するデータに示されている。膜貫通型のグリコホリンを 
data concerning glycophorin. Studies carried out with this integral membrane protein, reconstituted in vesicles (41), showed that the protein enhances the tendency of GM1 ganglioside to segregate in domains. In turn, glycosphingolipid segregation is able to strongly modify the glycoprotein conformation and oligomerization within the membrane, suggesting that integral membrane proteins and glycosphingolipid domains can affect and modulate each other.

Several studies are also indicate that a series of factors modulate the extent of glycosphingolipid segregation. For instance, it has been shown that interaction with external ligands (Cholera toxin, tetanus toxin, $\mathrm{Ca}^{2+}$ ) leads to a redistribution of glycosphingolipids, inducing their segregation $(29,47)$. Most interestingly, glycosphingolipid segregation is affected by specific events occurring at the membrane level. For instance, it has been shown in cultured neurons that protein kinase $\mathrm{C}$ (PKC) activation modulates ganglioside domains, inducing an increase in glycosphingolipid segregation in cell bodies (46). This interpretation also fits with the results observed in the same model system, showing that PKC activation (inducible by treatment with PMA or glutamate) changes the ganglioside exposure at the plasma membrane surface (26), and induces changes in the amount of ganglioside associated with the tyrosine kinase receptor $\operatorname{TrkB}(27,48)$. Both these results are attributable to a change of glycosphingolipid membrane distribution. It is interesting to point out that an event occurring at the cytoplasmic side of the membrane (PKC activation) induces a change of ganglioside concentration within the outer leaflet of the membrane. Anyway, it is worth noting that: a) GM1 interacts with integral membrane proteins; b) PKC activation induces redistribution of lipids and proteins, PKC included, in membrane domains (49). A likely hypothesis is that PKC-dependent phosphorylation of integral membrane proteins can modulate ganglioside segregation at the exoplasmic membrane face. This possibility would imply the involvement of ganglioside domains in a sort of outward-directed mechanism of signalling across the plasma membrane.

The picture described above also includes the possibility of cytoskeletal modifications, able to reorganize plasma membrane-associated molecules. Such speculation is suggested by the observation that tubulin is anchored to glycosphingolipidenriched domain of the neuronal plasma membrane (50) and that proteins of the MARCKS family, associated with membranes and the actin cytoskeleton, are well-known substrates for PKC (51).

\section{Function of Glycosphingolipids in Domains}

Among the most probable functions exerted by glycosphingolipids in domains is to concentrate proteins that play a role in transmembrane signaling events, and their regulated activation $(3,6)$. For example, the presence of receptor
含む再構成小包では、GM1のドメインへの凝集が立進している という報告もある。翻って、スフィンゴ糖脂質の相分離は糖夕 ンパク質の構造とオリゴマー形成に強く影響を与えている。つ まり、膜タンパク質と糖脂質ドメインがお互いに調節し影響し 合っていることを示唆している。

一連の因子がスフィンゴ糖脂質の相分離を調節しているこ とを幾つかの研究が示している。例えば、細胞外りガンド(コレ ラトキシン、テタヌストキシン、カルシウムイオン)がスフィン ゴ糖脂質の再分布と相分離を引き起こしている。興味深いこと に、スフィンゴ糖脂質の相分離は膜における特異的な現象に よって引き起こされる(46)。例えば、培養神経細胞においてプロ テインキナーゼCの活性化はドメインへのガングリオシドおよび 糖脂質の集積を元進させる。この結果の解釈は、モデル膜実験 において、PMAもしくはグルタミン酸によるPKCの活性化がガ ングリオシドの膜表面上への露出を促進し(26)、チロシンキナー ゼ受容体TrkBに相互作用するガングリオシドの量を変化させる という結果と一致する(27、48)。これら両方の結果は、スフィン ゴ糖脂質の膜における分布変化を引き起こしているという点で 一致している。これは細胞膜の細胞質側で起こる現象(PKC活性 化)が、膜の外側に存在するガングリオシドの濃度変化を引き起 こしているという点で興味深い。要約するとa) GM1が膜タンパ ク質と相互作用すること； b) PKCの活性化は膜ドメインにおい てPKCを含む脂質とタンパク質の再分布を引き起こすというこ と(49)は注目に值する。従って、膜たんぱくのPKCに依存した リン酸化は、膜外面のガングリオシドの相分離を調節している という仮説が提唱される。これは、ガングリオシドドメインが 細胞膜を介した外向きのシグナル伝達に関与していることを示 唆している。

ここで述べた概念には、細胞骨格の変化が、細胞膜に会合 する分子の再編成を可能にする可能性も含まれる。この予測 は、チューブリンが神経細胞膜の糖脂質ドメインにアンカーし ていることや、膜やアクチン骨格と会合しているMARCKSファ ミリータンパク質がPKCの基質となることから支持される。

D. ドメインにおけるスフィンゴ糖脂質の機能

ドメイン中のスフィンゴ糖脂質の予想されうる最も重要な 機能は、膜貫通シグナル伝達において役割を果しているタンパ ク質の膜への集積と、それらの活性化の調節である(3、6)。例え ば、チロシンキナーゼ受容体がスフィンゴ糖脂質ドメインに存 在することは、リガンド特異的なシグナル伝達にドメインが利 
tyrosine kinases within glycosphingolipid-enriched domains raises the possibility that specific ligands may use glycosphingolipid-enriched domains to carry out these processes. Several data are proving this hypothesis. It has been reported that GD3 ganglioside interacts with Lyn and that Lyn interacts with the neural cell adhesion molecule TAG-1 within the sphingolipid-enriched domains of neuronal cells (52). But Tag-1 signaling seems to require Lyn activation, and a recent report showed that the artificially induced depletion of glycosphingolipids at the cell surface is able to disrupt Lyn-mediated TAG-1 signaling and to interfere with the association of TAG-1 with the sphingolipid-enriched domain (53). Moreover, it is known that the NGF receptor, $\mathrm{p75}$, interacts specifically with GM1 ganglioside, and its activity is sensitive to ganglioside density $(27,45)$. Finally, the activity of TrkB, the tyrosine kinase receptor of the brain-derived neurotrophic factor (BDNF), is directly related to GM1 ganglioside density around the receptor itself $(27,48)$.

These data indicate that tyrosine kinases are among the proteins subjected to regulated activation within glycosphingolipid-enriched domains, and that an outbound signaling pathway may be activated by changes of glycosphingolipid density within glycosphingolipid-enriched domains (54).

Concerning human diseases, experimental data suggest that in Alzheimer's disease glycosphingolipid-enriched domains are involved in the release of amyloidogenic peptide (17). This localization may affect the molecular organization of domains and lead to abnormal signal transduction. Another disease in which the involvement of glycosphingolipid-enriched domains has been suggested are prion diseases (responsible for transmissible spongiform encephalopathies such as Creutzfeldt-Jakob disease and scrapie), in which a negative interference of misfolded prions with signal transduction can occur at this level.

\section{E. Conclusions}

Theoretical considerations about the peculiar physicochemical properties of glycosphingolipids and several experimental data suggest that they play an active role in the biogenesis of membrane lipid rafts. Moreover, the ability of these molecules to interact with other membrane components -either lipids and proteins- or with external ligands, suggests that glycosphingolipids play an important additional role in modulating domain dynamics and functions.

This research was supported in part by grants from MURST (Rome, Italy, Cofin 1999) and by CNR (Rome, Italy, 97.01225.PF49.115.25597).
用されている可能性が強い。幾つかのデータにより、この仮説 は証明されつつある。一つは、GD3がLynやLynと関与する神経 細胞接着分子TAG-1 と神経細胞の糖脂質ドメイン内で相互作用 している、という報告である(52)。TAG-1のシグナリングには Lynの活性化が必要であると考えられるが、人為的に細胞表面上 のスフィンゴ糖脂質を枯渴するとドメイン内のTAG-1 とLynの相 互作用が妨げられ、ドメインからTAG-1が解離するという事実が 最近報告された(53)。また別な報告では、NGFレセプターである $\mathrm{p} 75$ がGM1 と特異的に相互作用し、その活性化の程度はガングリ

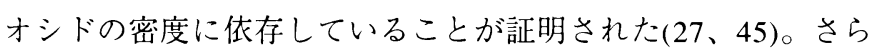
に、脳由来神経栄養因子(BDNF)のチロシンキナーゼ受容体であ るTrkBの活性化は近傍のGM1密度に直接的に関係している(27、 45)。これらのデータは、種々のチロシンキナーゼは糖脂質ドメ インにおいて活性制御を受けているタンパクの代表であり、また ドメインのスフィンゴ糖脂質密度の変化が外向きのシグナル伝達 経路を調節していること示している(54)。

ヒトの疾病に関わる実験データとしては、アルッハイマー病 に扔いてアミロイドßタンパク質の放出にスフィンゴ糖脂質ドメ インが関与しているという報告がある(17)。アミロイドßタンパ ク質のドメインへの集積は、ドメイン形成に影響し、異常なシグ ナル伝達を誘導しているかも知れない。

糖脂質ドメインが関わるその他の疾病としては、プリオン病 (クロイツフェルト-ヤコブ病やスクラピーなどの伝染性の脳障害 (スポンジ状脳形成) の原因である)がある。ミスフォールドされ たプリオンタンパク質は糖脂質ドメインに存在しシグナル伝達に 負に作用する可能性がある(武藤先生の章を参照されたい)。

\section{E. 結 論}

スフィンゴ糖脂質特有の物理化学的性質と幾つかの実験 デー夕に基づいて理論的に考察すると、スフィンゴ糖脂質は膜 脂質ラフトの形成に積極的に関わっていると言える。さらに、

スフィンゴ糖脂質分子は他の膜成分(脂質やタンパク質だけ でなく膜外のリガンドも含めて) と相互作用する能力があること から、ドメインの流動性や機能を調節する重要な役割も担って いる。

本総説に記載した我々の研究成果は、MURST(Rome, Italy, Coffin 1999) とCNR(Rome, Italy, 97.01225.PF49.115.25597)からの 研究助成を受けた。

北海道大学大学院薬学研究科 生体機能化学分野 樺山 一哉、井ノ口仁一 共訳 
Trends in Glycoscience and Glycotechnology Vol.13 No.71 (May 2001) pp.239-250

\section{References}

1. Thompson, T.E., and Tillack, T.W. (1985) Ann. Rev. Biophys. Chem. 14, 361-386

2. Simons, K., and Van Meer, G. (1988) Biochemistry 27, 6197-6202

3. Anderson, R.G.W. (1993) Proc. Natl. Acad. Sci. USA 90, 10909-10913

4. Masserini, M., Palestini, P., and Pitto, M. (1999) J. Neurochem. 73, 1-11

5. Oka, N., Yamamoto, M., Schwencke, C., Kawabe, J., Ebina, T., Ohno, S., Couet, J., Lisanti, M. P., and Ishikawa, Y. (1997) J. Biol. Chem. 272, 33416-33421

6. Lisanti, M.P., Scherer, P.E., Tang, Z., and Sargiacomo, M. (1994) Trends Cell Biol. 4, 231-235

7. Okamoto, T., Schelgel, A., Scherer, P. E., and Lisanti, M. P. (1998) J. Biol. Chem. 273, 5419-5422

8. Schnitzer, J. E., Liu, J., and Oh, P. (1995) J. Biol. Chem. 270, 14399-14404

9. Smart, E.J., Mineo, C., and Anderson, R. G. W. (1996) J. Cell Biol. 134, 1169-1177

10. Kurzchalia, T. V., and Parton, R. G. (1996) FEBS Lett. 389, 52-54

11. Brown, D., and Rose, J. K. (1992) Cell 68, 533-544

12. Cinek, T., and Horejsi, V. (1992) J. Immunol. 149, 2262-2270

13. Rothberg, K. G., Heuser, J. E., Donzell, W. C., Ying, Y., Glenney, J.R., and Anderson, R.G.W. (1992) Cell 68, 673-682

14. Sargiacomo, M., Sudol, M., Tang, Z., and Lisanti, M.P. (1993) J. Cell Biol. 122, 789-807

15. Moss, D.J., and White, C.A. (1992) Eur. J. Cell Biol. 57, 59-65

16. Ledesma, M. D., Simons, K., and Dotti, C.G. (1998) Proc. Natl. Acad. Sci. USA 95, 3966-3971

17. Wu, C., Butz, S., Ying, Y., and Anderson, R.G. (1997) J. Biol. Chem. 272, 3554-3559

18. Chigorno, V., Palestini, P., Sciannamblo, M. T., Dolo, V., Pavan, A., Tettamanti, G., and Sonnino, S. (2000) Eur. J. Biochem. 267, $4187-4197$

19. Prinetti, A., Chigorno, V., Tettamanti, G., and Sonnino, S. (2000) J. Biol. Chem. 275, 11658-11665

20. Parton, R. G. (1994) J. Histochem. Cytochem. 42, 155-166

21. Fra, A.M., Masserini, M., Palestini, P., Sonnino, S., and Simons, K. (1995) FEBS Lett. 375, 11-14

22. Olive, S., Dubois, C., Schachner, M., and Rougon, G. (1995) J. Neurochem. 65, 2307-2317

23. Vey, M., Pilkuhn, S., Wille, H., Nixon, R., DeArmond, S. J., Smart, E. J., Anderson, R. G., Taraboulos, A., and Prusiner, S. B. (1996) Proc. Natl. Acad. Sci. USA 93, 14945-14949

24. Sharom, F.J., and Grant, C. W., (1978) Biochim. Biophys. Acta 507, 280-293

25. Ferraretto, A., Pitto, M., Palestini, P., and Masserini, M. (1997) Biochemistry 36, 9232-9236

26. Palestini, P., Pitto, M., Ferraretto, A., Tettamanti, G., and Masserini, M. (1998) Biochemistry 37, 3143-3148

27. Pitto, M., Mutoh, T., Kuriyama, M., Ferraretto, A., Palestini, P., and Masserini, M. (1998) FEBS Lett. 439, 93-96

28. Goins, B., and Freire, E. (1985) Biochemistry 24, 1791-1797

29. Masserini, M., Giuliani, A., Palestini, P., Acquotti, D., Pitto, M., Chigorno, V., and Tettamanti, G. (1990) Biochemistry 29, 697-701

30. Riboni, L., Viani, P., Bassi, R., Prinetti, A., Tettamanti, G. (1997) Progress in Lipid Research 36, 153-195

31. Wiegandt, H. (1985) in "New Comprehesive Biochemistry" (Wiegandt, H., ed.) Glycosphingolipids 10, 199-260

32. Pascher, I. (1976) Biochim. Biophys. Acta 455, 433-451

33. Brocca, P., Berthault, P., and Sonnino, S. (1998) Biophysical J. 74, 309-318

34. Bach, D., Sela, B., and Miller, I.R. (1982) Chem. Phys. Lipids 31, 381-394

35. Acquotti, D., Poppe, L., Dabrowski, J., von der Lieth, G. W., Sonnino, S., and Tettamanti, G. (1990) J. Am. Chem. Soc. 112, $7772-7778$

36. Acquotti, D., Cantù, L., Ragg, E., and Sonnino, S. (1994) Eur. J. Biochem. 225, 271-288

37. Acquotti, D., Fronza, G., Ragg, E., and Sonnino, S. (1991) Chem. Phys. Lipids 59, 107-125

38. Pascher, I., and Sundel, S. (1977) Chem. Phys. Lipids 20, 175-191

39. Nyholm, P.G., and Pascher, I. (1993) Biochemistry 32, 1225-1234

40. Masserini, M., Palestini, P., and Freire, E. (1989) Biochemistry 28, 5029-5039

41. Terzaghi, A., Tettamanti, G., and Masserini, M. (1993) Biochemistry 32, 9722-9725

42. Schroeder, F., Nemecz, G., Wood, W.G., Joiner, C., Morrot, G., Ayraut-Jarrier, M., and Devaux, PF. (1991) Biochim. Biophys. Acta 1066, 183-192

43. Pitto, M., Brunner, J. Ferraretto, A., Ravasi, D., Palestini, P., and Masserini M. (2000) Glycoconjugate J. 17, $215-222$.

44. Cameron, P.L., Ruffin, J. W., Bollag, R., Rasmussen, H., and Cameron, R. S. (1997) J. Neurosci. 17, 9520-9535

45. Mutoh, T., Tokuda, A., Miyadai, T., Hamaguchi, M., and Fujiki, N. (1995) Proc. Natl. Acad. Sci. U.S.A. 92, 5087-5091

46. Pitto, M., Palestini, P., Ferraretto, A., Flati, S., Pavan, A., Ravasi, D., Masserini, M., and Bottiroli, G. (1999) Biochem. J. 343, 177-184

47. Calappi, E., Masserini, M., Schiavo, G., Montecucco, C., and Tettamanti, G. (1992) FEBS Lett. 309, 107-110

48. Palestini, P., Masserini, M., Bottiroli, G., Brunner, J., Mutoh, T., Ferraretto, A., Ravasi, D., and Pitto, M. (1999) Biosci. Reports 19, 385-395

49. Yang, L., and Glaser, M., (1996) Biochemistry 35, 13966-13974

50. Palestini, P., Pitto, M., Tedeschi, G., Ferraretto, A., Parenti, M., Brunner, J., and Masserini, M. (2000) J. of Biol. Chem. 275, $9978-9986$

51. Aderem, A. (1995) Biochemical Society Transactions 23, 587-591

52. Kasahara, K., Watanabe, Y., Yamamoto, T., and Sanai, Y. (1997) J. Biol. Chem. 272, 29947-29953

53. Kasahara, K., Watanabe, K., Takeuchi, K., Kaneko, H., Oohira, A., Yamamoto, T., and Sanai, Y. (2000) J. Biol. Chem. 275, 34701-34709

54. Benowitz, L. I., and Routtenberg, A. (1997) Trends Neurosci. 20, 84-91

55. Sonnino, S., Cantù, L., Acquotti, D., Corti, M., and Tettamanti, G. (1990) Chem. Phys. Lipids 52, 231-241

56. Cantù, L., Corti, M., Sonnino, S., and Tettamanti, G. (1990) Chem. Phys. Lipids 55, 223-229

57. Cantù, L., Corti, M., Sonnino, S., and Tettamanti, G. (1986) Chem. Phys. Lipids 41, 315-328

58. Sonnino, S., Acquotti, D., Fronza, G., Cantù, L., Chigorno, V., Pitto, M., Kirschner, G., and Tettamanti, G. (1988) Chem. Phys. Lipids 46, $181-191$

59. Cantù, L., Corti, M., Casellato, R., Acquotti, D., and Sonnino, S. (1991) Chem. Phys. Lipids 60, 111-118

60. Sonnino, S., Cantù, L., Corti, M., Acquotti, D., Kirschner, G., and Tettamanti, G. (1990) Chem. Phys. Lipids 56, 49-57

61. Sonnino, S., Acquotti, D., Cantù, L., Chigorno, V., Valsecchi, M., Casellato, R., Masserini, M., Corti, M., Allevi, P., and Tettamanti, G. (1994) Chem. Phys. Lipids 69, 95-104 


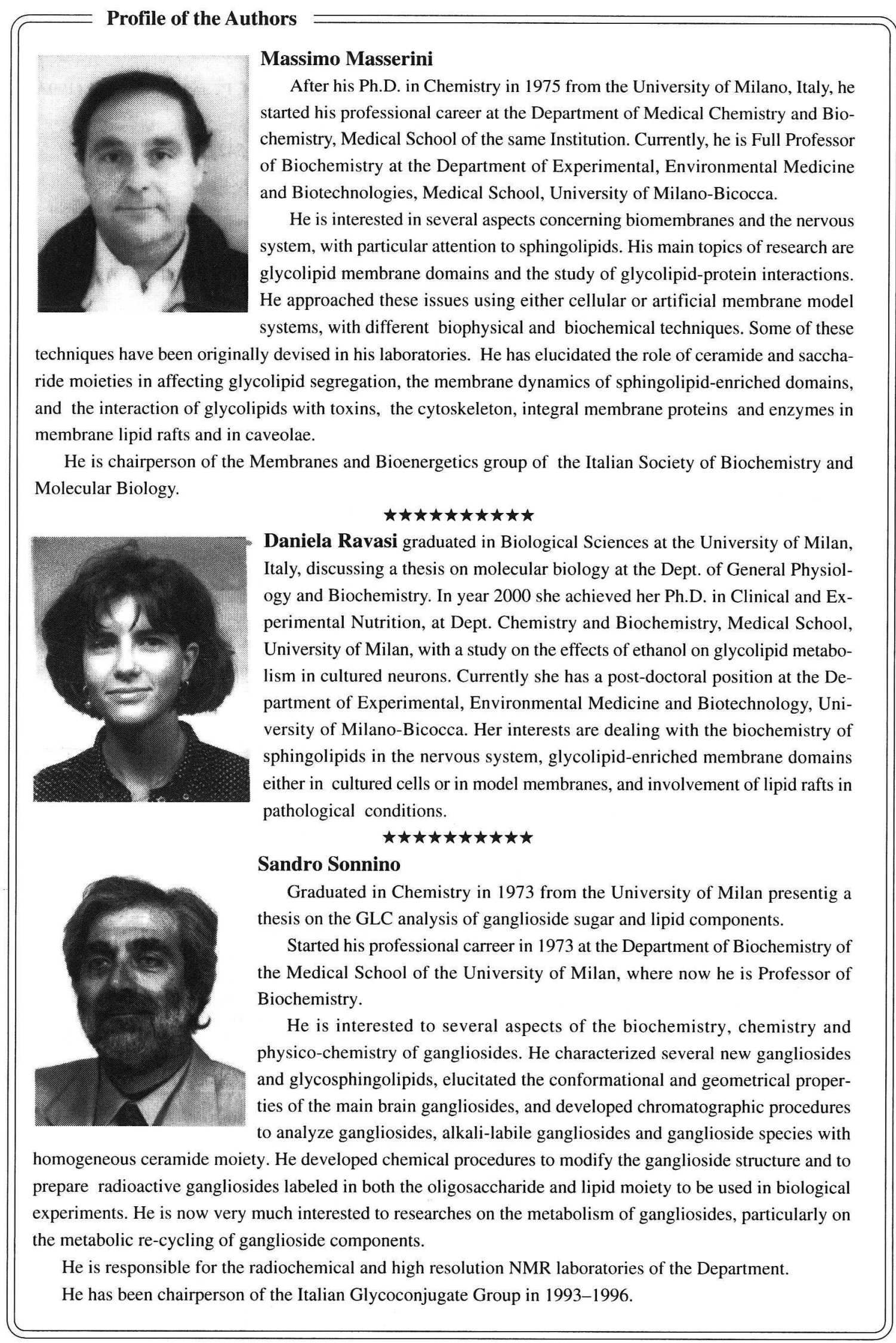

